Jurnal Laut Khatulistiwa, Vol. 3, No. 1 (Febuari, 2020), Hal. 31-39.

ISSN : 2614-6142 (Printed), 2614-8005 (Online)

http://jurnal.untan.ac.id/index.php/lk

JURNAL LAUT

KHATULISTIWA

\title{
Kepadatan dan Pola Distribusi Kima (Tridacnidae) di Perairan laut Desa Sepempang Kecamatan Bunguran Timur Kabupaten Natuna
}

\author{
Density and Distribution Pattern of Tridacnidae in Seawater in \\ Sepempang Village, East Bunguran District, Natuna Regency
}

\author{
Indah Peggy Triska Niwasdita ${ }^{{ }^{*}}$, Apriansyah ${ }^{1}$, Syarif Irwan Nurdiansyah ${ }^{1}$ \\ ${ }^{1}$ Laboratorium Ilmu Kelautan, FMIPA Universitas Tanjungpura, Pontianak, Indonesia \\ ${ }^{*}$ E-mail : indahpeggy17@gmail.com
}

Received : 9 October 2019; Accepted : 19 November 2019

Published: 27 Febuari 2020 (c) Author(s) 2020. This article is open access

\begin{abstract}
Tridacnidae is one of the protected biotas due to the decline in its population in nature. Tridacnidae lives in sandy substrate areas of protected coral reef ecosystems in tropical waters that are rather deep or shallow. Tridacnidae gets food by filtering or what is commonly referred to as an animal filter feeder. The purpose of this study was to determine the composition, density, and chemical distribution patterns as well as chemical physics parameters in Sepempang Village, East Bunguran District, Natuna Regency. This study consisted of four stations obtained using a purposive sampling method based on environmental bases, namely without a settlement, without settlement near rivers, docks, and settlements, while climatic data were collected using method belt transect. The results showed that 1 genus of 2 species, namely Tridacna crocea and Tridacna maxima. The highest density was T. crocea at 0.2 ind $/ \mathrm{m}^{2}$ at station III and the lowest at 0.058 ind $/ \mathrm{m} 2$ at station II, while T. maxima had the highest density at $0.007 \mathrm{ind} / \mathrm{m}^{2}$ at station II and the lowest was 0.001 ind $/ \mathrm{m}^{2}$ at station II. station I. Based on the Morisita Index, T. crocea has a clustered distribution pattern, while T. maxima have no known distribution pattern.
\end{abstract}

Keywords : Tridacnidae, distribution pattern, density, Natuna Regency

\begin{abstract}
Abstrak
Kima merupakan salah satu biota yang dilindungi akibat penurunan populasinya dialam. Kima hidup pada substrat berpasir daerah ekosistem terumbu karang yang terlindung di perairan tropis yang agak dalam maupun dangkal. Kima mendapatkan makanan dengan cara menyaring atau yang biasa disebut sebagai hewan filter feeder. Tujuan dari penelitian ini adalah mengetahui komposisi, kepadatan dan pola distribusi kima serta parameter fisika kimia di Perairan Laut Desa Sepempang Kecamatan Bunguran Timur Kabupaten Natuna. Penelitian ini terdiri dari empat stasiun yang diperoleh menggunakan metode purpossive sampling berdasarkan rona lingkungan yaitu tanpa pemukiman, tanpa pemukiman dekat aliran sungai, dermaga, dan pemukiman, sedangkan data kima diambil menggunakan metode belt transect. Hasil penelitian mendapatkan 1 genus 2 spesies yaitu Tridacna crocea dan Tridacna maxima. Kepadatan tertinggi yaitu T. crocea sebesar 0,2 ind/m2 pada stasiun III dan terendah sebesar 0,058 ind/m2 pada stasiun II, sedangkan T. maxima memiliki kepadatan tertinggi sebesar $0,007 \mathrm{ind} / \mathrm{m}^{2}$ pada stasiun II dan terendah sebesar $0,001 \mathrm{ind} / \mathrm{m} 2$ pada stasiun I. Berdasarkan Indeks Morisita, T. crocea memiliki pola distribusi mengelompok, sedangkan T. maxima tidak dapat diketahui pola distribusinya
\end{abstract}

Kata kunci : kima, poa distribusi, kepadatan, Kabupaten Natuna

\section{Pendahuluan}

Hutan Kabupaten Natuna memiliki potensi perairan laut dengan keanekaragaman ekosistem yang tinggi (Karlina, 2018), dimana kondisi suatu ekosistem sangat mempengaruhi biota yang hidup di didalamnya. Menurut Giyanto et al. (2017), kondisi ekosistem terumbu karang di perairan 
Jurnal Laut Khatulistiwa, Vol. 3, No. 1 (Febuari, 2020), Hal. 31-39.

laut Kabupaten Natuna memiliki status dari buruk sampai cukup baik. Berdasarkan Surat Keputusan Bupati Natuna Nomor 378 Tahun 2008, sebagian kawasan Kabupaten Natuna diperuntukkan sebagai Kawasan Konservasi Laut Daerah (KKLD) pada kegiatan COREMAP II (Coral Reef Rehabilitation and Management).

Desa Sepempang terletak di Pulau Bunguran Besar, Kecamatan Bunguran Timur Kabupaten Natuna Provinsi Kepulauan Riau dan termasuk ke dalam KKLD yaitu kawasan III yang meliputi pesisir timur Bunguran dan laut sekitarnya. Desa Sepempang memiliki perairan laut dengan potensi terumbu karang (BP3SP, 2008), yang merupakan habitat bagi biota laut termasuk kima (tridacnidae).

Kima (Tridacnidae) merupakan hewan yang memiliki tubuh lunak bercangkang dan termasuk dalam Kelas Bivalvia. Berdasarkan Surat Keputusan Menteri Kehutanan No. 12/Kpts/II/1987 Pemerintah Indonesia Tahun 1987 dan Peraturan Pemerintah No. 7 Tahun 1999 telah ditetapkan tujuh jenis kima yang hidup di Indonesia menjadi hewan yang dilindungi yaitu Tridacna gigas, T. derasa, T. maxima, T. squamosa, T. crocea, Hippopus hippopus, dan $H$. porcellanus. Pemerintah mengeluarkan peraturan mengenai penetapan kima sebagai hewan yang dilindungi karena populasinya di alam sudah sangat menurun, terutama disebabkan oleh pemanfaatan manusia. Hasil penelitian sebelumnya menunjukkan bahwa kepadatan kima di Perairan Pulau Wawosunggu Kabupaten Kanowe Selatan adalah $\left(0,06\right.$ ind $\left./ \mathrm{m}^{2}\right)$ (Hasni et al., 2017) dan di Desa Teluk Buton Kabupaten Natuna $\left(0,0071\right.$ ind $\left./ \mathrm{m}^{2}\right)$ (Suryanto et al., 2009).

Mengingat status kima sebagai hewan yang dilindungi dan penurunan jumlahnya di alam akibat eksploitasi berlebihan dan kerusakan habitat, diperlukan data atau informasi sebagai bahan acuan dalam mengambil langkah atau kebijakan mengenai pengelolaan kima. Hal tersebut menjadikan penelitian di Desa Sepempang Kecamatan Bunguran Timur Kabupaten Natuna sebagai bagian dari KKLD penting dilakukan untuk mendapatkan data ilmiah mengenai kepadatan dan pola distribusi jenis dari kima. Tujuan dari penelitian ini adalah mengetahui kepadatan dan pola distribusi kima serta parameter fisika kimia di Perairan Desa Sepempang Kecamatan Bunguran Timur Kabupaten Natuna.

\section{Metode}

\subsection{Waktu dan Tempat Penelitian}

Penelitian ini telah dilaksanakan pada Januari sampai Mei 2019 di Perairan Desa Sepempang Kecamatan Bunguran Timur Kabupaten Natuna (Gambar 1). Lokasi penelitian dilaksanakan di 4 stasiun berbeda

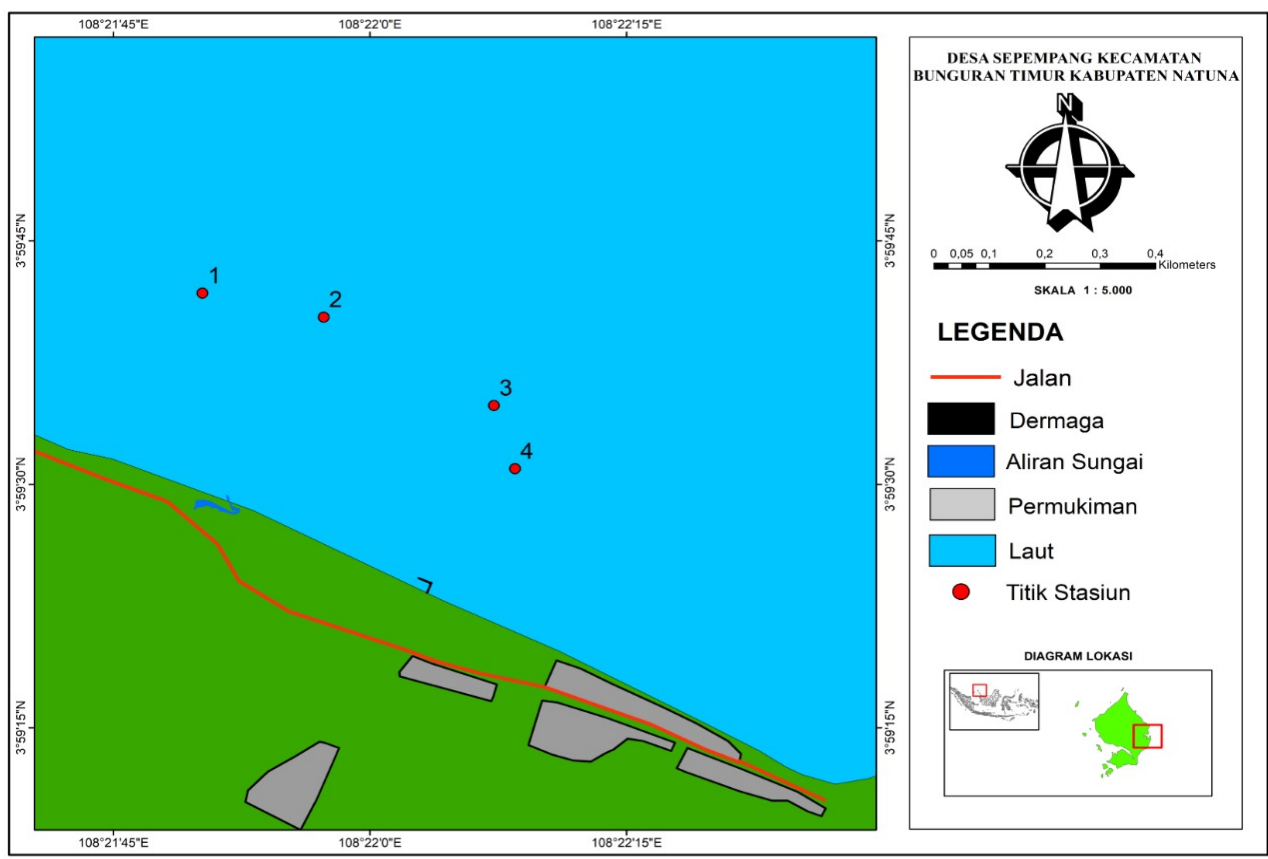

Gambar 1. Peta Lokasi penelitian di perairan Desa Sepempang 
Jurnal Laut Khatulistiwa, Vol. 3, No. 1 (Febuari, 2020), Hal. 31-39.

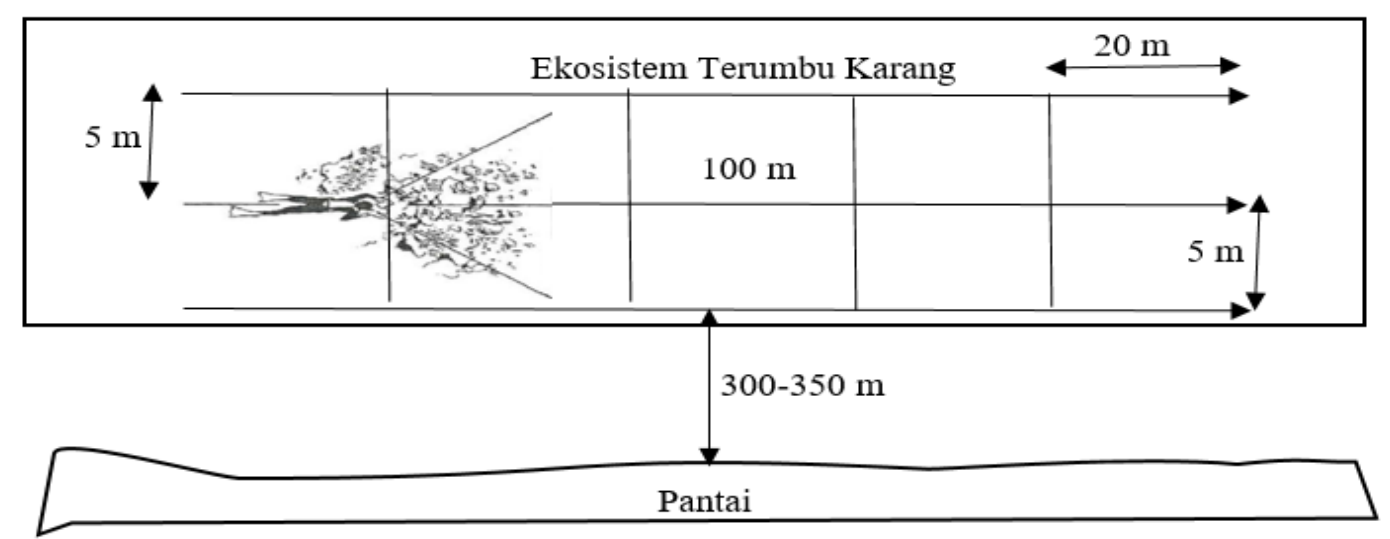

Gambar 2. Sketsa belt transect pengambilan data kima di perairan Desa Sepempang

yang ditentukan menggunakan metode purpossive sampling berdasarkan rona lingkungan yaitu stasiun 1 (zona tanpa pemukiman) dengan titik koordinat $\mathrm{N}$ 0359'41.76" E 10821'50.21", stasiun 2 (zona tanpa pemukiman dekat aliran sungai) $\mathrm{N}$

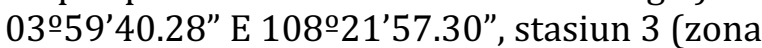
aktifitas keluar masuk kapal atau dermaga) $\mathrm{N}$ 0359'34.84" E 10822'07.25” dan stasiun 4 (zona pemukiman) N 0359'30.95" E $108^{\circ} 22^{\prime} 08.48^{\prime \prime}$.

\subsection{Pengambilan Data Kima}

Kategori kima yang masuk ke dalam pendataan adalah kima yang masih hidup. Data kima diambil menggunakan belt transect. Transek dibuat pada setiap stasiun dengan menarik garis sepanjang $100 \mathrm{~m}$ sejajar garis pantai dengan bantuan kompas. Setiap transek terdiri dari 5 plot dengan lebar daerah pengamatan $10 \mathrm{~m}$ (5 m kiri dan kanan), sehingga dapat dikatakan luas setiap plot adalah 20 x 10 m (Gambar 2). Data kima yang diambil meliputi jenis dan tipe substrat yang ditulis menggunakan kode yaitu CC (Coral Covered), DCA (Dead Coral Algae), POR (Porites), FAV (Faviidae), RB (Rubble), dan S (Sand). Identifikasi jenis kima dilakukan menggunakan panduan buku "Giant Clams" (Knop, 1996).

\subsection{Pengukuran Parameter Fisika-Kimia}

Parameter fisika-kimia yang diukur meliputi suhu, kecepatan arus, kedalaman, kecerahan, pH, salinitas dan DO (Dissolved
Oxygen). Hasil pengukuran parameter tersebut dijadikan sebagai data pendukung penelitian.

\subsection{Analisis Data}

Data pengukuran parameter fisika kimia dianalisis untuk mengetahui pengaruhnya terhadap kepadatan kima menggunakan software SPSS versi 24.0. Kepadatan kima dihitung menggunakan rumus yang mengacu pada Odum (1993):

$$
D=\frac{n}{A}
$$

dimana D adalah kepadatan kima (ind $/ \mathrm{m}^{2}$ ), $\mathrm{n}$ adalah jumlah individu suatu jenis (ind), dan $\mathrm{A}$ adalah luas transek pengamatan $\left(\mathrm{m}^{2}\right)$. Pola distribusi dihitung menggunakan indeks morisita:

$$
I d=n \frac{\sum x^{2}-\sum x}{\left(\sum x^{2}\right)-\sum x}
$$

dimana $I d$ adalah indeks morisita, $n$ adalah jumlah seluruh plot pengambilan sampel, $\sum \mathrm{x}^{2}$ adalah total dari kuadrat jumlah individu seluruh plot, $\sum x$ adalah total dari jumlah individu seluruh plot. Persamaan berikut dihitung terkait yang signifikan bagi indeks morisita (Krebs, 1989).

$$
M u=\frac{x^{2} \cdot 0,975-n+\sum x_{1}}{\left(\sum x_{i}\right)-1}
$$

$$
M u=\frac{x^{2} \cdot 0,025-n+\sum x_{1}}{\left(\sum x_{i}\right)-1}
$$

Dimana $\mathrm{Mu}$ adalah indeks keseragaman, Mc indeks pengelompokan, $x^{2} .0,975$ adalah nilai 
chi-square tabel dengan derajat bebas $\mathrm{n}-1$, $\mathrm{x}^{2} .0,025$ adalah nilai chi-square tabel dengan derajat bebas $n-1$, xi adalah jumlah individu dalam plot, dan $\mathrm{n}$ adalah jumlah seluruh plot pengambilan sampel. Standarisasi indeks morisita dihitung dengan salah satu rumus sebagai berikut (Krebs, 1989):

$$
\begin{aligned}
& I p=0.5+0.5\left(\frac{I d-M c}{n-M c}\right) \text { jika } I d \geq M c>1 \\
& I p=0.5\left(\frac{I d-1}{M u-1}\right) \text { jika } M c>I d \geq 1 \\
& I p=-0.5\left(\frac{I d-1}{M u-1}\right) \text { jika } 1>I d>M u \\
& I p=-0.5+0.5\left(\frac{I d-M c}{n-M c}\right) \text { jika } 1>M c>1
\end{aligned}
$$

\section{Hasil dan Pembahasan}

Proses pirolisis berlangsung \pm 8 jam dan menghaHasil penelitian yang dilakukan di Perairan Desa Sepempang ditemukan 1 genus dan 2 spesies. Genus yang ditemukan yaitu Tridacna, terdiri dari T. crocea (Gambar 3.a) dan T. maxima (Gambar 3.b) dengan total keseluruhan 505 individu. Masyarakat sekitar menamakan kedua jenis tersebut sebagai "pasek" untuk T. crocea dan "kima" untuk T. maxima. Kedua jenis dapat ditemukan pada semua stasiun namun dengan jumlah dan kepadatan yang bervariasi (Gambar 4). Kedua jenis yang ditemukan di Perairan Laut Desa Sepempang hidup dengan cara membenamkan seluruh atau sebagian cangkangnya pada karang sehingga sulit untuk diambil. Cappenberg (2007) juga menyatakan bahwa

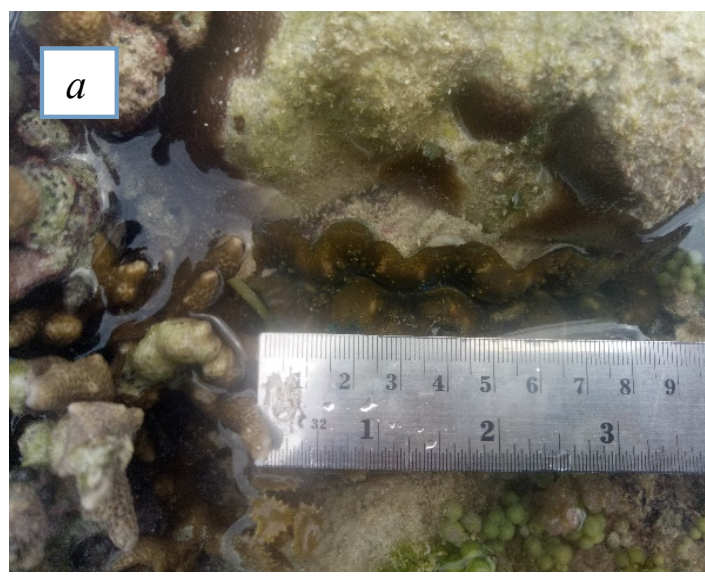

adanya hubungan erat terkait penempelan dengan benang byssus yang kuat dan membenamkan sebagian atau seluruh cangkangnya, sehingga kedua jenis tersebut masih dapat ditemukan.

Perbedaan kondisi habitat terkait faktor fisika kimia perairan dari masing-masing stasiun juga menjadi penyebab masih ditemukannya kedua jenis tersebut. Kusmana et al. (2015) menyatakan bahwa jumlah dan jenis biota yang ada di perairan dipengaruhi oleh faktor fisika-kimia, meliputi DO (Dissolve Oxygen) dan kedalaman. Nilai oksigen terlarut yang baik bagi pertumbuhan kima yaitu 6,3-9,6 $\mathrm{mg} / \mathrm{L}$ (Wakum et al., 2017). Hasil pengamatan menunjukkan DO pagi hari masih dalam kisaran yang dapat ditolerir oleh kima.

Jenis kima yang paling banyak ditemukan di Perairan Desa Sepempang yaitu T. crocea dengan jumlah 200 individu (Gambar 4) pada stasiun III. Hasil tersebut termasuk tinggi apabila dibandingkan dengan penelitian daerah lain, seperti di perairan Pulau Wawosunggu dengan jumlah 39 individu (Hasni et al., 2017), perairan Amdui Distrik Batanta Selatan sebanyak 78 individu (Wakum et al., 2017), Pesisir Morella sebanyak 41 individu (Widyasari et al., 2017), dan Perairan Singapura sebanyak 31 individu (Neo and Todd, 2012). Tingginya jumlah T. crocea yang ditemukan pada stasiun tersebut diduga karena rendahnya tingkat pengambilan, baik untuk konsumsi sehari-hari maupun diperdagangkan yang dilakukan oleh masyarakat sekitar. Pengambilan dilakukan dengan menggunakan alat yang dapat merusak karang kemudian kima yang menempel

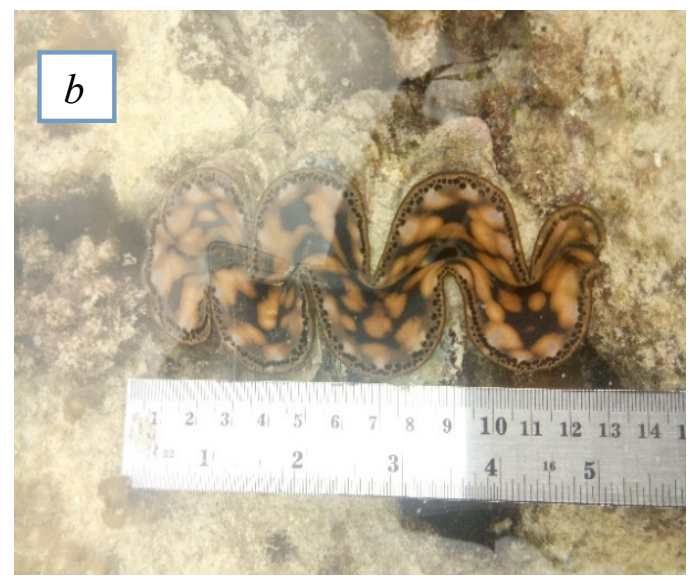

Gambar 3. Jenis T. crocea (a) dan T. maxima (b) di perairan Desa Sepempang 
Jurnal Laut Khatulistiwa, Vol. 3, No. 1 (Febuari, 2020), Hal. 31-39.

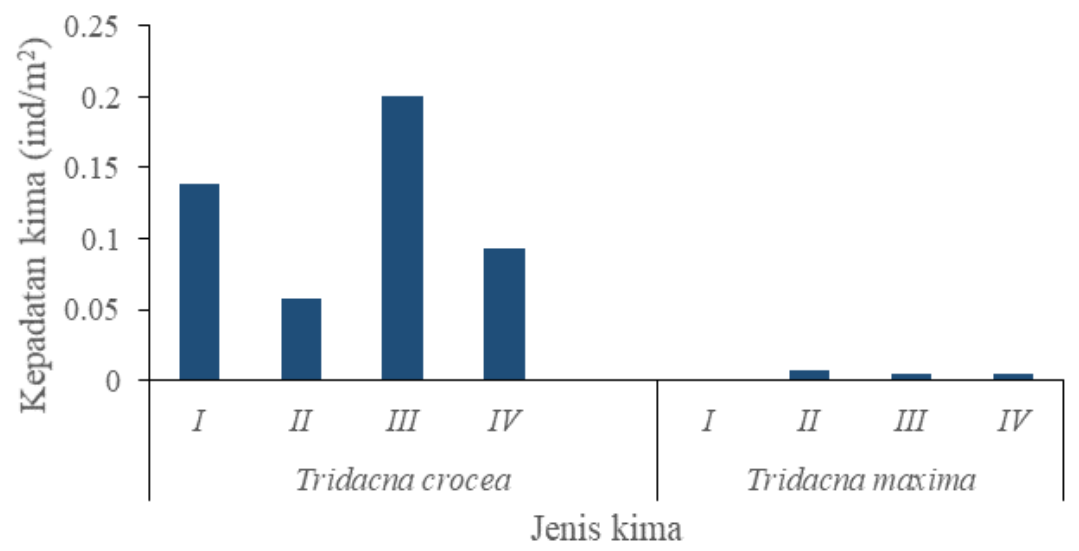

Gambar 4. Kepadatan jenis kima di perairan Desa Sepempang

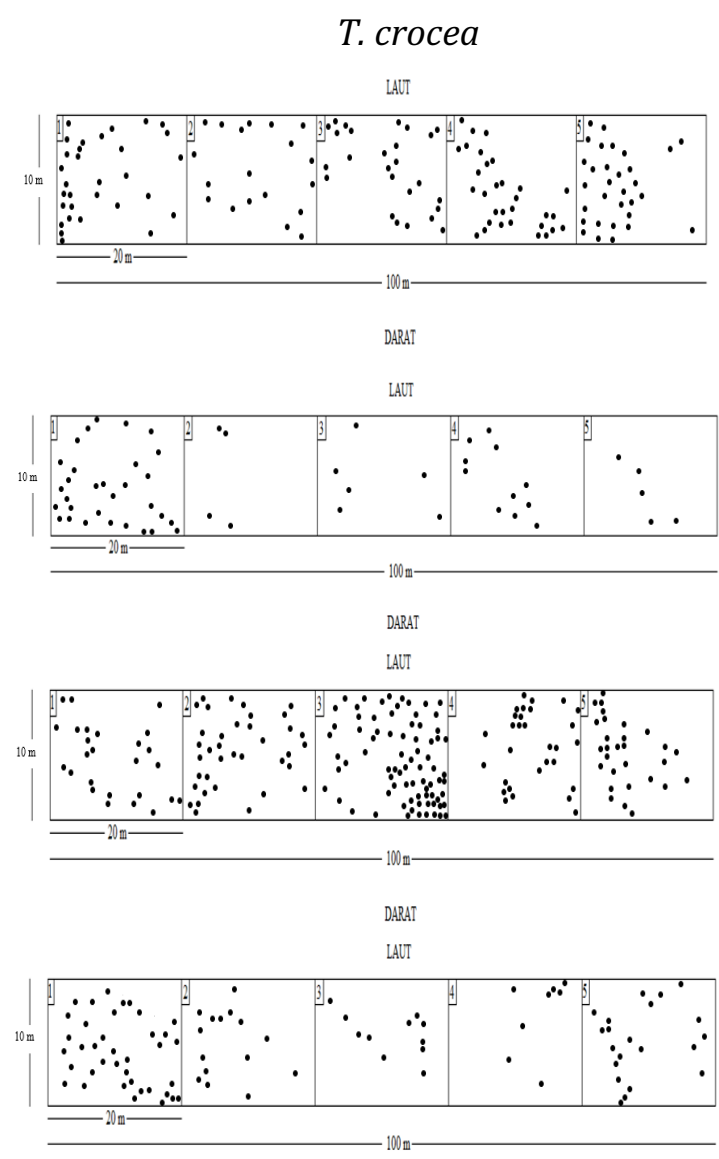

DARAT
T. maxima
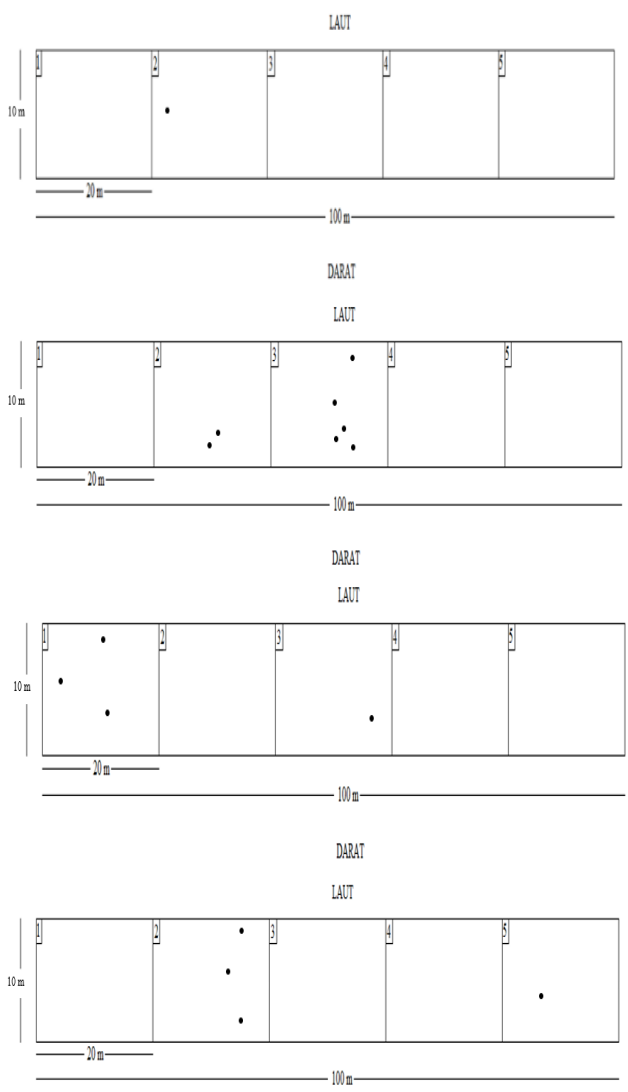

DARAT

Gambar 5. Sketsa pola distribusi kima di perairan Desa Sepempang

diambil. Kondisi habitat yang baik juga mempengaruhi jumlah individu yang ditemukan seperti ekosistem terumbu karang yang terjaga dan tidak rusak (Arby, 2010). Setiawan (2013) juga menyatakan bahwa populasi kima tergantung dari kondisi habitatnya yaitu terumbu karang, jika mengalami kerusakan maka berpengaruh terhadap jumlah dari kima tersebut.

Jenis T. crocea ditemukan dengan kepadatan tertinggi $(0,2$ ind $/ \mathrm{m} 2)$ pada stasiun III, sedangkan terendah pada stasiun II $(0,058$ ind $/ \mathrm{m}^{2}$ ) (Gambar 4). Kepadatan tinggi tersebut erat kaitannya dengan substrat tempat hidupnya. Hasil pengamatan menunjukkan 
Jurnal Laut Khatulistiwa, Vol. 3, No. 1 (Febuari, 2020), Hal. 31-39.

bahwa karang Porites mendominasi pada stasiun tersebut. Panggabean (1991) menyatakan bahwa $T$. crocea membutuhkan karang keras (massive) sebagai substrat untuk membenamkan diri sepanjang hidupnya. Berdasarkan pernyataan tersebut, dapat dikatakan bahwa substrat karang Porites yang mendominasi pada stasiun III mendukung untuk kehidupan kima dan memberikan pengaruh terhadap jumlah kima yang ada di daerah tersebut. Penelitian yang sama dilakukan Hasni et al. (2017) juga menunjukkan bahwa $T$. crocea hidup dan membenamkan diri pada karang massive yaitu Porites.

Kepadatan yang tinggi juga diduga karena $T$. crocea pada daerah stasiun III berhasil melakukan reproduksi, sehingga dapat meningkatkan jumlah kima yang hidup di daerah tersebut. Findra (2016) menyatakan bahwa tingginya kepadatan disebabkan oleh tingkat keberhasilan reproduksi sehingga meningkatkan jumlah kima yang hidup di perairan tersebut. Perairan laut dengan jumlah kima yang banyak menunjukkan bahwa ukuran populasinya besar, sehingga akan menjamin keberlangsungan reproduksi kima. Hal ini terjadi karena sel sel telur hasil reproduksi akan terbawa arus dan merangsang induk kima yang lain untuk melakukan reproduksi. Kepadatan T. crocea paling rendah terdapat pada stasiun II $(0,058$ ind $/ \mathrm{m}^{2}$ ). Hal ini diduga berkaitan erat dengan kondisi substrat dasar perairan yang ada di sekitar stasiun tersebut yang didominasi oleh karang Acropora. T. crocea hidup membenamkan diri pada substrat berupa karang Porites bukan hidup di sekitar perairan yang didominasi oleh karang Acropora (Calumpong, 1992).

Jenis T. maxima ditemukan sedikit pada masing-masing stasiun jika dibandingkan dengan T. crocea. T. maxima memiliki kepadatan paling tinggi $\left(0,007 \mathrm{ind} / \mathrm{m}^{2}\right)$ pada stasiun II, sedangkan terendah $\left(0,002\right.$ ind $\left./ \mathrm{m}^{2}\right)$ pada stasiun I. Menurut Panggabean (1991) dalam keadaan normal, kima memiliki reproduksi yang lambat, dengan demikian jika kegiatan ekploitasi yang berlebihan terus dilakukan maka jumlah populasi kima akan rendah. Masyarakat sekitar Desa Sepempang Kabupaten Natuna memiliki kebiasaan mengambil kima pada saat kondisi air surut. Kima yang diambil digunakan masyarakat untuk konsumsi maupun diperdagangkan.

Berdasarkan hasil pengamatan, pola distribusi dari masing-masing jenis dapat dilihat pada sketsa (Gambar 5.) Berdasarkan indeks morisita, $T$. crocea memiliki pola distribusi mengelompok dengan nilai Ip sebesar 0,5102. Pola distribusi mengelompok diduga karena adanya penumpukan bahan makanan pada daerah tersebut. Menurut Odum (1993), biota dengan pola distribusi mengelompok disebabkan oleh sifat bergerombol atau gregarious dan keragaman habitat sehingga menyebabkan pada suatu daerah yang banyak terdapat makanan terjadi pengelompokan. Beberapa penelitian yang telah dilakukan sebelumnya juga

Tabel 1. Parameter Fisika-Kimia di perairan Desa Sepempang

\begin{tabular}{cccccccccc}
\hline \multirow{2}{*}{ No } & \multirow{2}{*}{ Parameter } & \multicolumn{9}{c}{ I } & \multicolumn{2}{c}{ II } & \multicolumn{2}{c}{ III } & \multicolumn{2}{c}{ IV } \\
\cline { 3 - 11 } & & Pagi & Siang & Pagi & Siang & Pagi & Siang & Pagi & Siang \\
\hline 1. & Salinitas (ppt) & 33,5 & 33,6 & 33,6 & 33,2 & 33,6 & 33,3 & 33,6 & 33,4 \\
\hline 2. & Suhu ( $\left.{ }^{\circ} \mathrm{C}\right)$ & 28,3 & 28,5 & 28,5 & 28,8 & 28,4 & 28,4 & 28,3 & 28,4 \\
\hline 3. & Kedalaman (m) & 0,4 & 1,2 & 0,4 & 1,1 & 0,54 & 1,2 & 0,34 & 1,1 \\
\hline 4. & $\begin{array}{c}\text { Oksigen terlarut } \\
(\mathrm{mg} / \mathrm{L})\end{array}$ & 11,8 & 9,3 & 11,8 & 11,5 & 9,8 & 7,2 & 17,7 & 6,9 \\
\hline 5. & $\begin{array}{c}\text { Kecepatan arus } \\
(\mathrm{m} / \mathrm{s})\end{array}$ & 0,16 & 0,22 & 0,11 & 0,12 & 0,11 & 0,13 & 0,07 & 0,13 \\
\hline 6 & $\mathrm{pH}$ & 7,7 & 7,5 & 7,6 & 7,5 & 7,7 & 7,4 & 7,8 & 7,5 \\
\hline
\end{tabular}


menunjukkan bahwa T. crocea memiliki pola distribusi mengelompok di Perairan Pulau Karang Congkak Kepulauan Seribu (Rizkevina, 2014) dan di Perairan Teluk Nitanghahai Desa Morella Maluku Tengah (Ode, 2017) yang disebabkan oleh penumpukan makanan di lokasi tersebut.

Jenis kedua yaitu T. maxima tidak bisa ditentukan pola distribusinya karena analisis tidak bisa dilanjutkan ke tahap akhir yaitu analisis standar derajat morisita. Nilai indeks morisita tidak bisa didapat karena adanya plot dengan nilai frekuensi kehadiran sebesar nol atau beberapa plot ada yang tidak terdapat kima, sehingga tidak bisa mendapatkan nilai standar derajat morisita. Penelitian yang dilakukan Ode (2017) di Perairan Teluk Nitanghahai menunjukkan pola distribusi $T$. crocea mengelompok.

Parameter fisika-kimia penting dalam mendukung kehidupan biota. Berdasarkan data pengamatan, kondisi Perairan laut Desa Sepempang masuk dalam kategori optimal dalam mendukung kehidupan kima (Tabel 1). Salinitas memberikan pengaruh terhadap organ kima yaitu mantel (Knop, 1996). Salinitas yang tinggi menyebabkan cangkang tidak terbuka sepenuhnya dan mantel ditarik masuk, sedangkan salinitas rendah menyebabkan cangkang menutup dan mantel ditarik masuk serta mengakibatkan peradangan insang sehingga dalam jangka waktu tertentu kima akan mati (Knop, 1996). Salinitas di Perairan Laut Desa Sepempang masih dalam kategori baik bagi pertumbuhan kima yaitu 33,2-33,6 ppt (Gambar 6). Widyasari et al. (2016) menyatakan bahwa kisaran nilai salinitas yang baik dan masih dapat ditolerir oleh kima yaitu 33,06-33,54 ppt. Sama halnya dengan salinitas, suhu juga memberikan pengaruh yang sama terhadap mantel khususnya suhu yang tinggi (32-34), sedangkan suhu rendah menyebabkan kemampuan mantel dalam menerima rangsangan cahaya dan lingkungan sekitar menjadi lambat (Knop, 1996). Suhu di Perairan Laut Desa Sepempang berkisar 28,3-28,8. Penelitian sebelumnya dilakukan Litaay et al. (2007) menyatakan suhu optimum bagi pertumbuhan kima berkisar antara $28-31^{\circ} \mathrm{C}$.

Kusmana et al. (2015) menyatakan bahwa kedalaman mempengaruhi jumlah jenis dan jumlah individu suatu biota di perairan.
Kedalaman yang terukur di Perairan Laut Desa Sepempang secara berturut-turut berkisar antara 0,4-1,2 m. Oksigen terlarut penting bagi biota untuk proses metabolisme dan respirasi (Salmin, 2005). Oksigen terlarut di Perairan Laut Desa Sepempang berkisar antara 6,9-17,7 $\mathrm{mg} / \mathrm{L}$. Niartiningsih et al. (2008) menyatakan bahwa kima dapat hidup di perairan dengan kisaran nilai oksigen terlarut 6,6-11,7 mg/L.

Kecepatan arus memiliki peran penting bagi kehidupan biota seperti kima yaitu membawa oksigen terlarut, pengangkutan dan pertukaran nutrien dari suatu perairan ke perairan lainnya (Samawi et al., 2015). Berdasarkan pengamatan, kecepatan arus di Perairan Laut Desa Sepempang berkisar antara 0,07-0,22 m/s. Derajat keasaman (pH) memberikan pengaruh terhadap menurunnya daya tahan stress suatu biota. Kadar tinggi rendahnya $\mathrm{pH}$ dipengaruhi oleh kadar CO2 suatu perairan. Hamuna (2018) menyatakan bahwa nilai pH yang ideal bagi perairan untuk kehidupan biota di dalamnya berkisar antara 7-8,5. Kadar $\mathrm{pH}$ yang terukur di Perairan Laut Desa Sepempang berkisar antara 7,4-7,8. Berdasarkan analisis regresi, parameter suhu, kedalaman, dan kecepatan arus pada waktu pengambilan sampel berpengaruh positif terhadap kepadatan kima di Perairan Laut Desa Sepempang.

\section{Kesimpulan}

Komposisi kima terdiri dari 1 genus dan 2 spesies yaitu $T$. crocea dan $T$. maxima. Kepadatan kima tergolong rendah $(<1)$ pada semua stasiun. Kepadatan kima tertinggi yaitu $T$. crocea sebesar $0,2 \mathrm{ind} / \mathrm{m} 2$ pada stasiun III dan terendah stasiun II sebesar $0,058 \mathrm{ind} / \mathrm{m}^{2}$, sedangkan T. maxima memiliki kepadatan tertinggi sebesar 0,007 ind $/ \mathrm{m} 2$ pada stasiun II dan terendah pada stasiun I yaitu $0,002 \mathrm{ind} / \mathrm{m}^{2}$. T. crocea memiliki pola distribusi mengelompok, sedangkan T. maxima tidak dapat diketahui pola distribusinya karena syarat analisis standarisasi indeks moritsa tidak terpenuhi. Parameter fisika-kimia perairan memiliki rentang nilai optimal bagi pertumbuhan kima.

\section{Ucapan Terima Kasih}

Penulis mengucapkan terimakasih kepada Kementerian Riset, Teknologi, dan Pendidikan Tinggi Comdev \& Outreaching Universitas 
Jurnal Laut Khatulistiwa, Vol. 3, No. 1 (Febuari, 2020), Hal. 31-39.

Tanjungpura atas program beasiswa Bidikmisi yang telah memberikan dukungan finansial dalam penyelesaian penelitian ini.

\section{Daftar Pustaka}

Arbi, U.Y. 2010. Kepadatan dan Kondisi Habitat Kerang Kima (Cardiidae: Tridacninae) di Beberapa Lokasi di Perairan Sulawesi Utara. Jurnal. Bawal. 3:139-148.

Badan Penelitian dan Pengembangan Pemanfaatan Sumberdaya Perairan (BP3SP). 2008. Studi Kelayakan Untuk Pengembangan Keramba Jaring Tancap dan Rumput Laut di Wilayah Coremap Kabupaten Natuna. BP3SP. Fakultas Perikanan dan Ilmu Kelautan: Universitas Riau.

Calumpong, H.P. 1992. The Giant Clam: An ocean culture manual, Australian Centre for International Agricultural Research, Canberra.

Cappenberg, H. A. W. 2007. Sebaran dan Kepadatan Kima (Tridacnidae) di Perairan Kepulauan Derawan Kalimantan Timur. Jurnal Fish. Sci. 9:220-225.

Findra, M.N. 2016. Studi Populasi dan Profil Genetik Kima (Bivalvia, Cardiidae, Tridacnidae) di Perairan Taman Nasional Wakatobi. Tesis. Bogor: Institut Pertanian Bogor.

Giyanto. Muhammad, A. Tri, A.H. Agus, B. Muhammad, H. Abdullah, S. dan Marindah, Y.I. 2017. Status Terumbu Karang Indonesia Pusat Penelitian Oseanografi-LIPI. Jakarta.

Hamuna, B. Tanjung, R.H.R. Suwitno. Maury, H.K. dan Alianto. 2018. Kajian Kualitas Air Laut dan Indeks Pencemaran Berdasarkan Parameter Fisika-Kimia Di Perairan Distrik Depapre Jayapura. Jurnal Ilmu Lingkungan. 16:35-43.

Hasni. Baru, S. dan Ira. 2017. Keanekaragaman dan Kepadatan Jenis Kima di Perairan Pulau Wawosunggu Kabupaten Konawe Selatan. Jurnal Sapa Laut. 2:113-118.

Karlina, I. 2018. Evaluasi Keberlanjutan Pengelolaan Kawasan Konservasi Perairan Daerah (KKPD) Kawasan I, Kawasan II dan Kawasan III Kabupaten Natuna. Jurnal Dinamika Maritim. 2:63-70.

Knop, D. 1996. Giant Clams, a Comprehensive Guide to the Identification and Care of
Tridacnid Clams, DahneVerlag, Ettlingen, 251.

Krebs, C. J. 1989. Ecological Methodology. New York: Harper Collins Publisher.

Kusmana, C. Setyobudiandi, I. Hariyadi, S dan Sembiring, A. 2015. Sampling dan Analisis Bioekologi Sumber Daya Hayati Pesisir dan Laut. Edisi ke-1. Indonesia: IPB Press.

Litaay, M. Gobel, R.B. Abdullah, A. Alie, K dan Lejab, S. 2007. Kualitas Media Pemeliharaan Larva Lola Merah dan Kima Sisik Hasil Filtrasi Bertingkat di Hatchery. Jurnal Ilmu Kelautan. 12:24-30.

Neo, M.L. and Peter. A.T. 2012. Populations Density and Genetic Structure of the Giant clams Tridacna crocea and T. squamosa on Singapore's Reefs. J. Aquat. Biol. 14:265275.

Niartiningsih, A. Litaay, M. Suryati, E. dan Prasetiawan, I. 2008. Pemeliharaan Juvenil Kima Sisik (Tridacna squamosa) dan Lola (Trochus niloticus) Secara Monokultur dan Polikultur pada Kedalaman Berbeda di Perairan Pulau Badi Kabupaten Pangkep. Prosiding Simposium Terumbu Karang II. Jakarta, Indonesia.

Ode, I. 2017. Kepadatan dan Pola Distribusi Kerang Kima (Tridacnidae) di Perairan Teluk Nitanghahai Desa Morella Maluku Tengah. Jurnal Agrikan. 10:2.

Odum, E.P. 1993. Dasar-Dasar Ekologi, T. Samingan (alih bahasa.). Yogyakarta: Gadjah Mada University Press.

Panggabean, L.M.G. 1991. Rahasia Kehidupan Kima: II. Evolusi. Jurnal Oseana. 16:35-44.

Rizkevina, Q. 2014. Keanekargaman Jenis dan Distribusi Family Tridacnidae (Kerang Kima) di Perairan Pulau Karang Congkak, Kepulauan Seribu. Skripsi. Jakarta: Universitas Islam Negeri Syarif Hidayatullah.

Samawi, M.F. Faisal, A. dan Rani, C. 2015. Parameter Oseanografi pada Calon Daerah Kawasan Konservasi Perairan Laut Kabupaten Luwu Utara. Prosiding Simposium Nasional Kelautan dan Perikanan II. Makassar, Indonesia.

Salmin. 2005. Oksigen Terlarut (DO) dan Kebutuhan Oksigen Biologi (BOD) Sebagai Salah Satu Indikator Untuk Menentukan Kualitas Perairan. Jurnal Oseana. 30:21-26.

Setiawan, H. 2013. Ancaman Terhadap Populasi Kima (Tridacnidacna sp) dan 
Jurnal Laut Khatulistiwa, Vol. 3, No. 1 (Febuari, 2020), Hal. 31-39.

Upaya Konsevasinya Di Taman Nasional Taka Bonerate, Info Teknis EBONI, 10:137147.

Suryanto, H. Yulianda, F. dan Wardiatno, Y. Analisis Status Terumbu Karang Untuk Pengembangan Wisata Bahari di Desa Teluk Buton Kabupaten Natuna. 2009. Jurnal Ilmuilmu Perairan dan Perikanan Indonesia. 2:137-143.

Wakum, A. Muhammad, T. dan Selfanie, T. 2017. Jenis-Jenis Kima dan Kelimpahannya di Perairan Amdui Distrik Batanta Selatan Kabupaten Raja Ampat. Jurnal Sumberdaya Akuatik Indopasifik. 1:1.

Widyasari, F. Santoso, B.W. Gulam, A. Didik, S. M. Nasrul, L. dan Arif Reza, F. 2016. Pengujian Kualitas Air di Perairan Pantai Negeri Morella Sebagai Habitat Kima (Tridacna sp.). Jurnal Airaha. 5:109-121.

Widyasari, F. Gulam, A. Robiandi. Didik, S. Syahid, R. M. Nasrul, L. Arif, F.R. Kiki, R.A. and Mohammad, S. 2017 Distribution, Density and Identifacation of Giant Clams in Coastal Area of Negeri Morella, The District of Leihitu, Central Maluku Regency, Indonesia. Russian Journal of Agricultural and Socio-Economic Sciences. 9:69. 